\title{
THE EUROPE 2020 PROJECT BOND INITIATIVE: AN ALTERNATIVE TO FINANCE INFRASTRUCTURE IN EUROPE
}

\author{
José Manuel VASSALLO ${ }^{a}$, Thais RANGEL ${ }^{a}$, María de los Ángeles BAEZA $^{\text {, }}$, \\ Paola Carolina BUENO ${ }^{\mathrm{a}}$ \\ ${ }^{a}$ Transport Research Center (TRANSyT), Universidad Politécnica de Madrid, \\ ETSI Caminos, Canales y Puertos. C/ Profesor Aranguren s/n. 28040 Madrid, Spain \\ ${ }^{b}$ Department of Financial Economic and Accounting, Universidad de Granada, \\ Campus Universitario de La Cartuja, 18011 Granada, Spain
}

Received 08 October 2014; accepted 10 April 2016

\begin{abstract}
The economic and financial crisis that struck Europe over the last few years has imposed much stricter capital and liquidity requirements for commercial banks thereby reducing their ability to provide funding to infrastructure projects. To circumvent this problem the European Union has promoted the Europe 2020 Project Bond Initiative (PBI) aimed at using European funds for credit enhancement to increase the appetite of institutional investors - such as pension funds and insurance companies - to boost large-scale infrastructure financing. In this paper we describe the specific constraints and attractiveness of the PBI within Europe using the SWOT methodology to analyse the information coming from both pilot case studies and the responses that institutional investors and other stakeholders provided to the EC public consultation about the PBI. On the basis of this information we found that even though the initiative may contribute to facilitate infrastructure financing in Europe, there are still some challenges to be addressed for its right implementation.
\end{abstract}

Keywords: infrastructure financing, project bonds, European Union, institutional investors, economic recession, capital markets, SWOT analysis.

JEL Classification: G, H54, O18.

\section{Introduction}

The 2020 Agenda of the European Commission envisages a huge infrastructure volume between $€ 1.5$ and $€ 2.0$ trillion - to invest in energy, transport and information and communication technology (ICT) facilities to promote growth, employment, and convergence across the regions. However raising long-term financing for infrastructure has become a challenge ever since the economic recession struck Europe in 2008.

Corresponding author José Manuel Vassallo

E-mail: jvassallo@caminos.upm.es 
The financial crisis has prompted the implementation of measures to improve the regulation, supervision and risk management of the banking sector. These measures imposed much stricter capital and liquidity requirements for commercial banks to provide financing for large-scale projects thereby having a strong effect on the financing of infrastructure. As a consequence of this, the need for new financial sources to attract investors for infrastructure projects in Europe has been widely emphasized (Scannella 2012; Jacobsson, R., Jacobsson, S. 2012; Zaharioaie 2012; Hellowell 2013). After the financial crisis the financing of long term infrastructure projects has been evolving from mere "bank-based" to "market-based" approaches (Jacobsson, R., Jacobsson, S. 2012).

With the aim to increase strategic infrastructure investment and reduce bottlenecks, in 2010 the European Commission launched the Europe 2020 Project Bond Initiative (PBI). The idea behind the PBI consist of using EU funds for credit enhancement to increase the appetite of institutional investors - such as pension funds and insurance companies - to finance large scale infrastructure of interest for Europe. Institutional investors seem to be potential buyers of long-term project financing securities (Scannella 2012; Bassanini, Reviglio 2011; European Commission 2011a; Della Croce, Yermo 2013). This initiative recognizes the capital markets as an alternative source for funding infrastructure projects.

In order to obtain feedback about this initiative from different stakeholders, the European Commission (EC) launched a public consultation on the Europe 2020 Project Bond Initiative (European Commission 2011b, 2011c, 2013a). The conclusions from the consultation were used by the EC to fine tune the PBI implementation.

The aim of this study is twofold; first, to determine the specific constraints and attractiveness of the PBI within Europe; and second, to point out some critical aspects to tackle for the successful implementation of this initiative. To this end, we used the SWOT methodology on the basis of (1) worldwide literature about project bonds for financing infrastructure, (2) the responses that institutional investors and other stakeholders provided to the EC public consultation about the PBI, and (3) pilot case studies (Castor Gas Storage Spain, Greater Gabbard offshore UK, A11 Belgian motorway, A7 Autobahn Germany and Axione Telecom Infrastructure France). This paper makes an interesting contribution to the state of the art and practice since, at the time of the witting of this paper, there are few research works analyzing in detail the 2020 PBI.

The paper is structured as follows. Section 1, right after the introduction, explains the role of project bonds to finance infrastructure by describing their pros and cons and identifies the appetite of institutional investors. Section 2 shows the experiences worldwide, explains the reasons why the 2020 PBI were proposed by the EU, and describes the implementation of this initiative. Section 3 explains the methodology and the information used to analyse the problem. Section 4 provides a critical analysis and results. Finally, last Section concludes and presents some key challenges for the successful implementation of a project bond market in Europe. 


\section{The role of project bonds to finance infrastructure: pros and cons}

There are few research studies about the role of project bonds as a means of financing large-scale infrastructure projects. Some authors focus on the main characteristics of the project bond market for a specific type of infrastructure (Hellowell 2013; Scannella 2012; Jacobsson, R., Jacobsson, S. 2012), or on infrastructure projects in general (Rossi, Stepic 2015; Gatti 2013; EIB, 2012, 2010; Bhattacharyay 2010).

Several financial instruments or initiatives were developed to encourage economic growth due to the European debt crisis. Their main objective was to ensure the necessary financing of EU priority projects. Zaharioaie (2012) describes some initiatives such as: JESSICA aimed at attracting additional financing for urban development; LGTT Loan Guarantee Ten-Transport to mitigate traffic risk in the ramp-up period of large transport projects, RSFF (Risk Sharing Finance Facility) that is a credit risk sharing instrument aimed at supporting PPP projects in the research, technological and innovation domain; ELENA aimed at supporting the public investment in energy; and the Europe 2020 Project Bond Initiative (PBI), which is the focus of this paper.

The PBI was promoted by the European Commission and the European Investment Bank (EIB) as a means of encouraging new financial instruments to make infrastructure projects more attractive to investors (European Commission 2011b). The PBI aims to promote the development of capital markets for financing European infrastructure projects for transport, energy and information technology and communication. Thus, project bonds are an alternative source to bank loans and public financing. The PBI intends to reduce the dominance of commercial banks in infrastructure financing in Europe, and promote the contribution of alternative investors.

Commercial banks are the most common financial sources for global project finance in the world (Esty et al. 2014). However, the global financial crisis has resulted in stricter regulations on banks and their lending requirements. Despite the traditional strength of bank financing, particularly in Europe, commercial banks are undergoing important constraints to finance new projects or to refinance existing ones. Both the credit crunch that impacted the biggest world economies in 2008 and the sovereign debt crisis in Europe that threatened the credibility of the euro currency have had an important impact on the way that banks and financial markets behaved ever since. This instability largely constrained long-term financing for large-scale infrastructure in Europe.

The new regulation for banks in Europe, called Basel III, established more conservative rules in order to guarantee the resilience of banks to unexpected events. Basel III is a framework agreement by the Bank for International Settlements in December 2010 (Dhondt et al. 2014). Its purpose is to reinforce the financial system after the crisis. The application of Basel III to the financial European system was made through the Directive 2013/36/UE and the Regulation 575/2013 that began to be applied on January 1st 2014 (European Commission 2014c).

This agreement introduced two ratios of liquidity: Liquidity Coverage Ratio (LCR) and NetStable Funding Ratio (NSFR). The LCR demands to the banks to support sufficient liquid assets that are high quality to resist 30 days in a scene of financing under tension 
specified by the supervisors. The LCR had to reach a value of $60 \%$ to $01 / 01 / 2015$ and has to increase annually up to reaching a value of $100 \%$ in January 2019. On the other hand, the NSFR is a structural long-term indicator designed to relieve imbalances of liquidity, this indicator covers the totality of the balance and offers incentives to the banks in order that they resort to stable financing sources. In summary, Basel III imposed much greater capital and liquidity requirements to risky long-term lending, thereby reducing the ability of banks to structure complex project finance deals that used to be common in the past.

Such instability in the banking system can delay or even stop the implementation of important investment projects (Herring, Chatusripitak 2000; Dhondt et al. 2014). In response to this problem, some proposals are emerging to narrow the long-term financing gap. Many stakeholders point to the bond market as one of the promising means for financing largescale infrastructure projects in the future.

Project bonds are not a new phenomenon; they have been used for financing projects in the US, Canada and Asia for more than 15 years (Latham, Watkins 2009). Despite the fact that project bond financing has always played a minimal role in project finance globally (Blanc-Brude 2014), its importance is increasing. As shown by Esty et al. (2014), in 2013, bank loans financed 584 projects around the world while bonds financed 249 projects, compared to 538 and 114, respectively in 2012 . From a sector perspective, a very large majority of all project bond capital between 2011 and 2013 went to finance infrastructure, oil and gas, and power. In the case of bank lending most has been concentrated in the power, transportation and oil and gas sectors (see Fig. 1).

It is important to note that from 2011 to 2013 , the sector with one of the lowest growth was social infrastructure, as presented in Table 1. Social Infrastructure comprises facilities supporting the community such as hospitals, education, prisons, housing, recreation and leisure, stadiums, etc. The PBI should attract institutional investors to promote more social infrastructure. The government may use regulation to achieve wider social objectives. If the objective of all parties of the regulatory contract is purely to maximise their own utilities, it would be very hard to promote both market and social efficiencies to be achieved (OECD 2013).

The bond market for large-scale infrastructure is typically addressed to institutional investors such as insurance companies and pension funds since they have long-term investment needs that match quite well with the long-term nature of infrastructure assets. Nevertheless, insurance companies and pension funds have to meet the standards required by the Solvency II Directive. This rule intends to safeguard the principle of prudence in the investment policy of institutional investors. To this end, it requires these institutions to invest in assets whose risks can be clearly identified, measured, monitored, managed, controlled and properly notified. All assets must be invested so as to guarantee the safety, liquidity and profitability of the portfolio. Consequently, the needs of institutional investors do not necessarily match with the investment characteristics of certain projects (Christophersen et al. 2014; Siemiatycki 2013; OECD 2013; Scannella, 2012; Della Croce 2011; Della Croce, Gatti 2014). Long term investors are characterized by a low reliance on short term-market liquidity due to stable resources, low risk and long term returns. 
a)

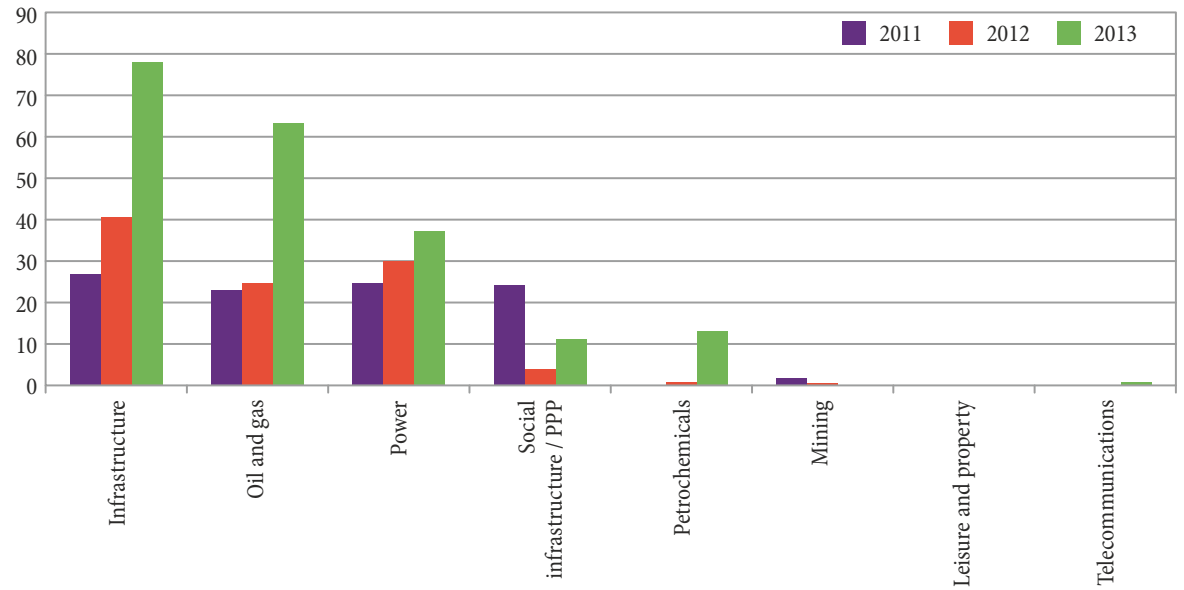

b)

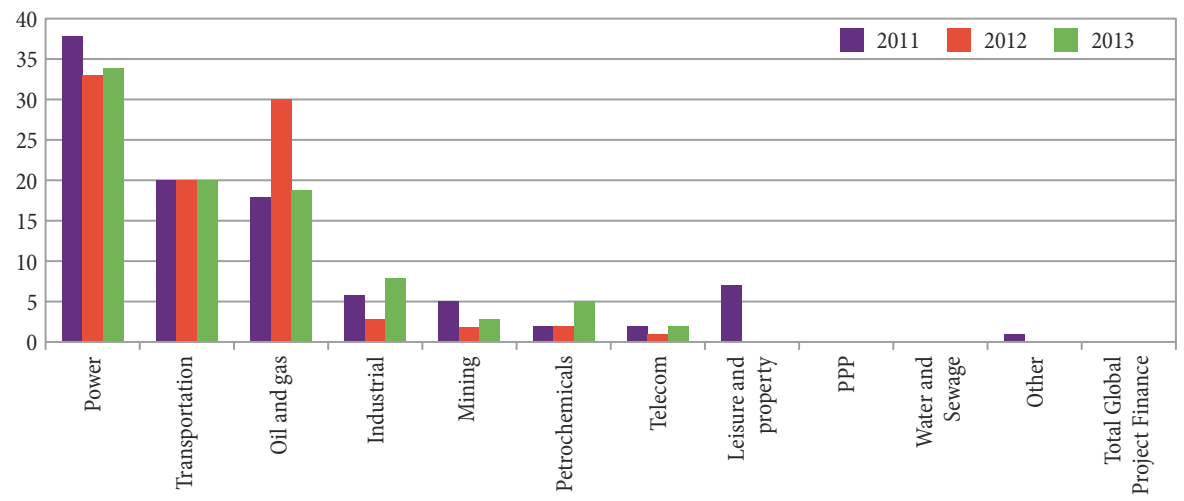

Fig. 1. Project Finance bonds and Project Finance lending by sector (2011-2013) Source: Esty et al. 2014.

Table 1. Project Finance Bonds by Sector ( $\$$ million)

\begin{tabular}{lccccc}
\hline \multicolumn{1}{c}{ Sector } & 2011 & 2012 & 2013 & Total 2011-2013 & Percentage of Total \\
\hline Infrastructure & 6.033 & 9.796 & 18.884 & 34.713 & $36.29 \%$ \\
\hline Oil \& Gas & 5.148 & 5.905 & 15.315 & 26.368 & $27.56 \%$ \\
\hline Power & 5.448 & 7.108 & 9.099 & 21.655 & $22.64 \%$ \\
\hline Social Infrastructure/PPP & 5.315 & 961 & 2.643 & 8.919 & $9.32 \%$ \\
\hline Petrochemical & 0 & 183 & 3.200 & 3.383 & $3.54 \%$ \\
\hline Mining & 335 & 174 & 0 & 509 & $0.53 \%$ \\
\hline Leisure \& Property & 0 & 0 & 0 & 0 & $0 \%$ \\
\hline Telecommunications & 0 & 0 & 114 & 114 & $0.12 \%$ \\
\hline Total & 22.279 & 24.127 & 49.255 & 95.661 & $100 \%$ \\
\hline
\end{tabular}

Source: Esty et al. 2014. 
The main obstacles for the project bond progress are the following (Rossi, Stepic 2015; Gatti 2013; EIB 2010): (1) commercial banks still assume capital markets as competitors since project finance has been traditionally the major source of fee business for banks; (2) borrowers are generally more comfortable with banks and fear the vulnerability associated with capital markets (lack of early commitments, inflexibility of a market dictating its conditions); (3) investment bankers and advisors, in some cases, may be interested to develop this business but will only invest the considerable up-front costs necessary to arrange complex project bonds if they see a real perspective of repeated progresses; (4) bond investors (unlike banks) are less inclined to run risks associated with the construction phase, preferring to assume risks only in the operational phase.

It would appear that the facilitation of institutional investment depends as much on the development of long term relationships of trust between financial intermediaries and institutional investors as on a robust contractual agreement with the government (OECD 2013, 2014).

There are also other important issues for large infrastructure financing such as: cost overruns, delays, failed procurement, inadequate designs, organizational risks and technological risks. The cause of these issues is mostly inappropriate risk allocation. To avoid those problems, it is crucial to identify risk factors from project inception to delivery. Sometimes there is no a connection between contractual obligations and transparency about a contractor's ability to deliver so the society ends up bearing the costs of failures or overruns (Beckers et al. 2013; Marowa, Muyengwa 2015). The PBI was presented by the EC as a cheap way to finance infrastructure in the EU. This lower financing cost should be good for society as long as the saving is higher than the guarantee cost of the PBI borne by the EU.

Finally there is also a corruption risk involved in project bond operations. It raises crucial questions as to how to select projects for inclusion in the Project Bond Credit Enhancement. However the EIB has the main responsibility for the adoption of fraud prevention measures (corruption, fraud, collusion, coercion, money laundering and the financing of terrorism in European Investment Bank activities).

\section{Infrastructure project bonds worldwide}

The investment needs of institutional investors have almost doubled in a decade. In 2012 they held global assets under Management (AuM) totalling \$62.4 trillion (Boston Consulting Group 2013). This situation is boosting project bonds worldwide. However, project bonds are not a new phenomenon since this approach has been extensively used in some countries. In this section we first describe the experience of using project bonds for financing infrastructure in the world; and, after that, we introduce the implementation of the PBI in Europe.

\subsection{Previous experience worldwide}

Till the implementation of the 2020 Project Bond Initiative, the experience of using project bonds for financing infrastructure in continental Europe was much more limited than in other areas of the world. In the United Kingdom however project bonds have been used 
more often. Under the new programme called "Private Finance 2" (PF2) for hospital financing in the UK, the tender processes require bidding consortia to develop proposals in which pension funds and insurance companies provide the majority of the debt finance (Hellowell 2013).

In the US the market for PPPs has been fuelled by the enormous amounts of cash that pension funds and insurance companies need to invest (Brown 2007). Project bonds have been promoted by the government through certain programmes such as the Transportation Infrastructure Finance and Innovation Act (TIFIA), and Private Activity Bonds (PAB). The TIFIA program was launched in 1998 to promote federal credit assistance for transportation projects under the U.S. Department of Transportation. TIFIA provides credit support for transport projects that would not otherwise be financially viable. The program was designed to fill market gaps by providing projects with subordinate debt. The amount of the credit assistance may not exceed $33 \%$ of total eligible project costs. PABs in their turn are one way of making up the amount not funded under TIFIA. Both TIFIA and PAB provide substantial incentives for private equity investment (Abadie, MacGray 2013; Daito et al. 2013; FHWA 2009). Some relevant projects in the USA financed with project bonds are: The Pocahontas Parkway (Route 895) in 2002, Maritimes \& Northeast Pipeline in 2009, Black Hills Power Plant in 2009, Congestion Relief Program (CRP) Open Roads for a Faster Future in 2009, and State Route 190 in 2011 among others.

Infrastructure bonds are also common for financing PPPs in Canada. Unlike European banks, Canadian banks are unable to lend on a long term basis. This situation accentuated because of the economic recession so the bond market for infrastructure financing in Canada significantly expanded ever since 2008 (Abadie, MacGray 2013). Some recent projects that were funded through the bond market in this country are Alberta Schools Phase III (2012), Highway 407 East Extension (2009) and Plenary Health Niagara (2009).

In Latin America we can highlight the Brazilian and Chilean experience. Three transactions were completed in 2010 in Brazil. Odebrecht's Rotas das Bandeiras raised 1.1 billion reals (US\$623 million) for 12 years from the Brazilian market for its operating Dom Pedro highway. This transaction is considered as an important opening of the project bond market to Brazilian infrastructure projects. Schahin Group’s Lancer issued a US\$270 million bond with a term of six years to the Brazilian and international markets to refinance its offshore drill ship chartered to Petrobras. And, Odebrecht sold a US\$1.5 billion, 10-year project bond to the international capital markets to refinance two nearly completed drilling vessels (Mbeng Mezui 2012). In Chile, all the big energy firms such as Gener, Colbún and Enersis issue bonds on a regular basis in both the domestic and foreign markets. In 2008, the corporate bond market represented $11.4 \%$ of the GDP of the country. Infrastructure bonds for PPP projects were $20 \%$ of this total. Pension funds and insurance companies hold more than $90 \%$ of the stock of infrastructure bonds in Chile. A reason for this is that private pension funds are very large in the country (Mbeng Mezui 2012).

\subsection{The Europe 2020 Project Bond Initiative}

In order to encourage the participation of institutional investors to improve the credit quality of the senior debt the EU has launched the PBI. According to Rossi and Stepic (2015) 
this initiative may have a strong effect in promoting capital market financing and increasing access to institutional funding in Europe.

The PBI is founded on the fact that the EU, through the EIB, may provide either a layer of subordinated debt or a stand-by liquidity facility to the project in order to reduce the exposure to the project risk by senior lenders. The subordinated layer of debt will reduce the senior debt tranche while the stand-by liquidity facility will provide funding if the revenues generated by the project are not sufficient to repay the senior debt. These two forms of financing are guaranteed by the European Commission up to a certain level thereby improving the credit quality of the senior debt. The Special Purpose Vehicle (company incharge of the project) would divide its debt into two layers: a senior debt to be placed with institutional investors, and a subordinated debt obligation which would be underwritten by the EIB (see Fig. 2). The EIB is responsible for evaluating and selecting projects with their own rules, structure the financing instrument, and monitor projects.

A pilot phase to test this mechanism was agreed by the Commission for the period 2007-2013 in collaboration with the EIB. This pilot phase was included in the Regulation (EU) No. 670/2012 (European Commission 2014a). In November 7th 2012 the Commission and the EIB signed a cooperation agreement to share revenues and risks between the two institutions. In December $21^{\text {st }} 2012$ the EIB published a draft of the initiative.

The European Commission is responsible for establishing the criteria and for providing the EIB the capital necessary to improve the rating of the bonds. The 2007-2013 pilot phase committed $€ 230$ million of the EU budget. Nine pilot projects were approved in six Member States during the pilot phase: (1) Castor Gas Storage Spain, (2) Greater Gabbard offshore

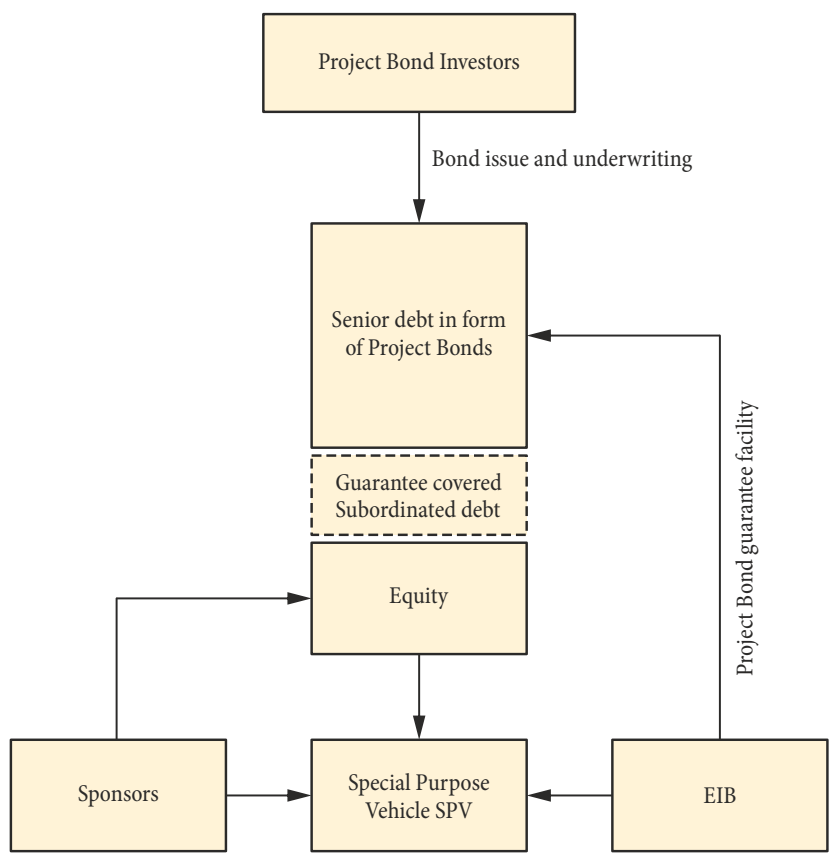

Fig. 2. EU Project Bonds

Source: Authors' figure based on European Commission (2011b). 
UK, (3) A11 Motorway Belgium, (4) Axione Telecom Infrastructure France, (5) Autobahn A7 Germany, (6) Passante di Mestre motorway Italy, (7) N25 New Ross motorway Ireland, (8) A45 motorway France, (9) A7 Phase 2 Germany (European Commission, 2014a). At the time of writing this paper, the first five projects have already been approved by EIB. In the next section we provide information about these case studies.

\section{Methodology and data}

To determine the specific constraints and attractiveness of the PBI within Europe we apply a SWOT analysis on the basis of the data and information obtained from the case studies of the pilot phase and also the responses that institutional investors and other stakeholders provided to the EC public consultation about the PBI (European Commission 2013a). Unfortunately, we were not able to implement a quantitative analysis because the PBI is still a very new initiative in Europe so there is not enough data to conduct a statistical approach. Besides the first transaction of the PBI was made in July 2013 (Castor Gas Storage Spain) so the track record of the pilot projects is too short.

The SWOT analysis is a commonly-used qualitative tool for analyzing positive and negative factors related to a new product, technology, management or planning in order to support a strategic decision. It was first used in the 1960s as an approach for improving business management strategies in contexts characterized by uncertainty and high competitiveness (Hill, Westbrook 1997). However in recent years the SWOT analysis has been adapted to wider fields of application (Baycheva-Merger, Wolfslehner 2016; Comino, Ferretti 2016; Jaber et al. 2015).

From the methodological point of view, the SWOT analysis includes two categories of factors: internal factors (strengths and weaknesses) which are part of the system and can be directly modified by the promoters of the initiative, and external factors (opportunities and threats) which are external to the system but may influence it.

The first step of this research is to identify and adjust the definitions of the SWOT factors (strengths, weaknesses, opportunities and threats) to the purposes of this study.

The data used to apply the methodology came from two different sources: (1) the public consultation launched by the EU about the PBI and (2) pilot case studies to document experience from real cases.

\subsection{Public consultation}

Before launching the idea of a new risk-sharing instrument aimed at facilitating the connection between capital markets and infrastructure financing, the European Commission (EC) wanted to know whether key stakeholders were receptive to the initiative, and had something to add. To that end, on February $28^{\text {th }} 2011$ the EC launched a public consultation on the Europe 2020 Project Bond Initiative. This section provides a general overview of the survey process, and outlines some of the results of the public consultation. This survey allowed us obtaining market participants' and decision makers' feedback on the chosen mechanism and its essential terms and conditions. In addition, the results of the consultation are of value on its own, as they constitute an important data source for this analysis. 
Unfortunately, the disaggregate data of the survey is not available, so it is not possible to use statistical and econometric tests to obtain conclusions on the basis of them.

A structured 7-point survey questionnaire was developed to know the opinion of different stakeholders. Respondents were asked to give their opinion and perception on the Europe 2020 PBI, including its feasibility, its efficiency and costs, as well as the budget and framework implications of the mechanism.

The questionnaire was sent to different contributors. In the end 131 questionnaires were received. Respondents belonged to the following categories: 1) financial institutions such as banks, financial intermediaries, funds, insurance companies and connected association $(33 \%) ; 2)$ operators, infrastructure developers and connected associations (28\%); governments (12\%); and other groups - including consultants, researchers, legal firms and other associations - (27\%). Figure 3 shows the share of different groups.

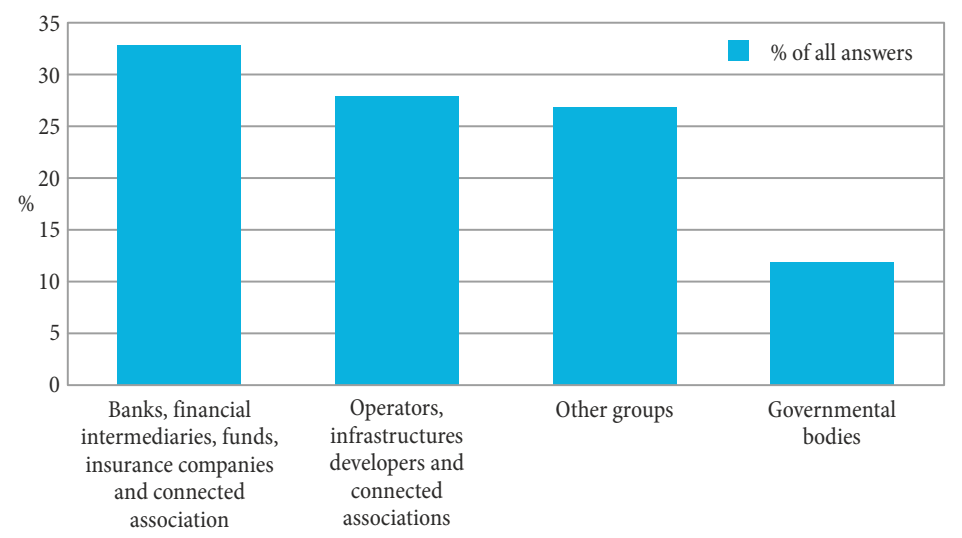

Fig. 3. Profile of the respondents

To analyze the opinion of the stakeholders, we reviewed written responses available online. On the basis of the questions included in the consultation questionnaire, we have identified the following five topics: (1) feasibility and management of project bonds, (2) cost and efficiency of project bonds, (3) sectorial implementation, (4) public budget and market distortion, and (5) environmental issues. While all are important, in this paper we will focus only on the first two topics because the main aim of this initiative is to help private developers to draw funding through the capital markets from investors such as pension funds and insurance companies. Since a detailed description of the last three topics is out of the scope of this paper, interested readers are advised to look into the European Commission website for greater detail.

Overall financial institutions and institutional investors regard the PBI in a fairly positive way even though they consider that infrastructure debt will remain heavily dominated by banks. However, their decision to invest will finally be determined by the risk-return characteristics, as well as by the liquidity in the project bond market, solvency and other regulatory requirements.

Table 2 shows the questions and a summary of the responses of the survey regarding the feasibility and management of project bonds. 
As previously described, the PBI is currently conceived as a cost effective financing alternative whose main goal is complementing existing sources of financing. In order to explore how the overall proposal may comply with this role, the public consultation included the two questions whose answers are summarized in Table 3.

Table 2. Summary of the responses to the questions of the consultation regarding feasibility and management of project bonds

$\begin{array}{lll}\text { Question of the consultation } \quad \text { Total agree respondents } & \begin{array}{l}\text { No full agree } \\ \text { respondents }\end{array}\end{array}$

\begin{tabular}{lll}
\hline $\begin{array}{l}\text { 1. Is the chosen mechanism likely to } \\
\text { attract private sector institutional } \\
\text { investors to the sectors of transport, } \\
\text { energy and ICT in particular? If } \\
\text { you are an investor, would you be } \\
\text { prepared to buy such project bonds? }\end{array}$ & $\begin{array}{l}60 \% \text {. The chosen mechanism is likely } \\
\text { to attract private sector institutional } \\
\text { investors to the sectors of transport, } \\
\text { energy and ICT in particular. }\end{array}$ & $\begin{array}{l}16 \% \text { It depends } \\
\text { on technical features } \\
\text { of thechanism } \\
\text { structure or rating. }\end{array}$ \\
\hline $\begin{array}{l}\text { 2. Is it essential that a single entity } \\
\text { acts as controlling creditor? }\end{array}$ & $\begin{array}{l}\text { For a 33\% it would be essential, } \\
\text { especially during the conclusion } \\
\text { of the financial package and the } \\
\text { construction phase. For 15\% of } \\
\text { stakeholders it would be beneficial. } \\
\text { Finally, 10\% of participants would } \\
\text { expect the EU or the EIB to serve as }\end{array}$ & $\begin{array}{l}11 \% \text {. A single } \\
\text { controlling creditor } \\
\text { is not necessary. }\end{array}$ \\
& a controlling creditor. \\
\hline
\end{tabular}

\begin{tabular}{ll}
\hline \multicolumn{1}{c}{ Question of the consultation } & \multicolumn{1}{c}{ General answer } \\
\hline $\begin{array}{l}\text { 3. What minimum rating of the } \\
\text { bonds would be sufficient to attract } \\
\text { investors? }\end{array}$ & $\begin{array}{l}\text { A Minimum rating of A- is sufficient to attract investors } \\
\text { but the desirable minimum rating would depend on the } \\
\text { project size (A- or A for big projects, BBB or BBB + for } \\
\text { small projects). }\end{array}$ \\
$\begin{array}{ll}\text { 4. What degree of credit enhancement } \\
\text { would be necessary to achieve this }\end{array}$ & $\begin{array}{l}\text { A credit enhancement of 20\% of outstanding senior bonds } \\
\text { would be sufficient for 10\% of respondents, whereas 5\% } \\
\text { of them believe that it would not be enough. }\end{array}$ \\
\hline
\end{tabular}

Table 3. Summary of the responses to the questions of the consultation regarding cost and efficiency of project bonds

\begin{tabular}{|c|c|c|}
\hline Question of the consultation & Total agree respondents & No full agree respondents \\
\hline $\begin{array}{l}\text { 1. Would the credit enhancement } \\
\text { facilitate/accelerate the conclusion } \\
\text { of financing packages? }\end{array}$ & $\begin{array}{l}41 \% \text {. The guarantee would } \\
\text { facilitate, accelerate or both } \\
\text { the conclusion of financing } \\
\text { packages. }\end{array}$ & $\begin{array}{l}15 \% \text { depends, } 6 \% \text { doubtful and } \\
38 \% \text { disagree. It will depend on } \\
\text { the way European Commission } \\
\text { implement the mechanism, its } \\
\text { terms and conditions. }\end{array}$ \\
\hline
\end{tabular}

\begin{tabular}{ll}
\hline \multicolumn{1}{c}{ Question of the consultation } & \multicolumn{1}{c}{ General answer } \\
\hline $\begin{array}{l}\text { 2. Which impact would the } \\
\text { Initiative have on financing costs } \\
\text { and on maturities? }\end{array}$ & $\begin{array}{l}50 \% \text { of stakeholders expect lower financial costs and/or longer } \\
\text { 20\% expect it to depend on different factors such as regulation, } \\
\text { guarantee, rating or pricing. }\end{array}$ \\
\hline
\end{tabular}




\subsection{Case studies - pilot phase}

We also obtain interesting feedback from the five PBI pilot cases (Castor Gas Storage Spain, Greater Gabbard offshore UK, A11 Belgian motorway, Axione Telecom Infrastructure France and A7 Autobahn Germany) which are described in greater detail below.

\section{Castor Gas Storage Spain}

The Castor project was the first transaction of the PBI taking place in July 2013 in Spain. It was an underground gas storage plant located in Spain's Mediterranean coast with the capacity to provide storage for $30 \%$ of Spain's daily gas consumption. The public promoter was the Spanish Ministry of Industry. The project partners were ACS Group (66\%) and Dundee Energy. The amount of the issue was $€ 1.4$ billion, with an annual coupon of $5.75 \%$ payable semi-annually at par and maturity at 21.5 years (until 2034). A large percentage of the issue, $80 \%$, was subscribed by foreign investors. The EIB contributed with $€ 500$ million to this project, $€ 200$ million for liquidity, and $€ 300$ million for purchasing bonds. Santander Bank acted as the global coordinator for this transaction.

Originally Fitch assigned a BBB+ rating to the bonds while Standard \& Poor's rated them with BBB. The bonds were issued at the Luxembourg Stock Exchange. However, after some earthquakes recorded in the area, apparently caused by the injection of gas, the government of Spain decided to stop the work. As a consequence of this event Fitch announced that it placed the rating on negative watch because there was "significant uncertainty" about the project. In late October 2013 the Supreme Court of Spain dismissed the appeal filed by the government against the provision for compensation to the operator, the concessionaire of gas storage in the event of termination or expiration of the grant, even when negligent (European Commission 2014a; Rossi, Stepic 2015).

The Castor project was the less successful project of the PBI pilot phase due to the poor risk allocation along with social and environmental impacts.

\section{Greater Gabbard offshore UK}

At the end of 2013 the first PBI issue in the UK took place for the Greater Gabbard offshore transmission link. The aim of this project is to build transmission assets to transfer energy from the 140-turbine wind farm off the Suffolk coast to the UK mainland electricity. The amount of the issue was $£ 305$ million, maturing in 20 years. The EIB guaranteed $£ 45.8$ million, representing $15 \%$ of the bond issued and allowing a step up in Moody 's (A3). The Greater Gabbard OFTO was the first deal under the project bond initiative where the credit enhancement was directly backed by the EU budget (European Commission 2014a; Rossi, Stepic 2015).

\section{A11 Belgian motorway}

In late March 2014, the EIB backed the A11 Belgian motorway link. This motorway is the first transport project - and the first greenfield PPP in Europe - to benefit from the EC-EIB Project Bond Initiative. The aim of this project is to reduce congestion for freight and tourist traffic. This will provide a direct motorway connection between the port of Zeebrugge and the European motorway network, removing congestion and delays on the heavily used route. 
The design-build-finance-maintain project through the project company Via A11 is being financed by a public-private consortium, Allianz Global Investors (€433 million) and EIB ( $€ 145$ million). Deutsche Bank is acting as the global coordinator. To that end $€ 577.9$ million of project bonds were issued for the A11. The fixed-rate coupon is of 4.49 per cent, and the final redemption date is in September 2045 (31.5 years). The EIB provided a subordinated credit facility of $€ 115$ million, which improved the credit rating of the bonds by three notches to A3 according to the rating agency Moody's. The bonds will be amortized gradually after the construction period. The Belgium A11 deal is known as one that has delivered great value for money (European Commission 2014a; Rossi, Stepic 2015).

\section{Axione Telecom Infrastructure France}

It was the first project bond in France and Europe involving digital infrastructure. The project will allow to provide broadband services (xDSL, fibre optics, FTTx and some minor investments in wireless access technologies) in areas with low density of population.

The investor is a holding company, Axione Infrastructure, of which 55\% is held by FIDEPPP (an infrastructure fund sponsored by entities of the BPCE Group and managed by Mirova), $30 \%$ by Caisse des Dépôts et consignations and 15\% by Bouygues Construction Group. The total cost is about $€ 142$ million. The EIB is financing approximately $€ 58$ million for the project.

The works had limited environmental effects, apart from disturbances during civil work constructions.

\section{A7 Autobahn Germany}

The first financing operation in Germany with EU project bonds closed in late August 2014. The project A7 concerns the extension of motorway between the Bordesholm junction in Schleswig-Holstein and the Hamburg Nordwest junction. During the construction period, traffic will keep on flowing. The project company is paid on the basis of availability payments.

The total financing is up to $€ 770$ million. The duration of the concession is 30 years. The EIB is providing a subordinated loan of around $€ 90$ million for the project, representing about $20 \%$ of the volume of the senior debt through the issuance of capital market instruments. The bond investors were EIB, AXA, KfW IPEX, MassMutual, Aegon, ING and Sun Life (European Commission 2014a; Rossi, Stepic 2015).

Table 4 provides an overview of the main characteristics of the five case studies.

Table 4. Case studies

\begin{tabular}{ccccccc}
\hline Name & Country & Sector & $\begin{array}{c}\text { Green or } \\
\text { Brown field }\end{array}$ & Duration & $\begin{array}{c}\text { Financial } \\
\text { close date }\end{array}$ & $\begin{array}{c}\text { Investment } \\
\text { amount }\end{array}$ \\
\hline Castor & Spain & Energy & brownfield & 30 years & $\begin{array}{c}\text { September } \\
2013\end{array}$ & $€ 1,4 \mathrm{bn}$ \\
\hline $\begin{array}{c}\text { Greater } \\
\text { Gabbard }\end{array}$ & UK & Energy & brownfield & 30 years & $\begin{array}{c}\text { November } \\
2013\end{array}$ & $£ 305 \mathrm{~m}$ \\
\hline A11 & Belgium & Road & greenfield & 30 years & March 2014 & $€ 578 \mathrm{~m}$ \\
\hline $\begin{array}{c}\text { Axione } \\
\text { Infrastructure }\end{array}$ & France & Telecommunication & brownfield & $\begin{array}{c}\text { Not } \\
\text { available }\end{array}$ & July 2014 & $€ 142 \mathrm{~m}$ \\
\hline A7 & Germany & Road & brownfield & 30 years & August 2014 & $€ 770 \mathrm{~m}$ \\
\hline
\end{tabular}


The pilot phase of the PBI plays a very important role for the future of the initiative. Overall, the pilot experiences have proved that project bonds may be a real alternative to finance infrastructure facilities. Institutional investors such as pension funds and insurance companies have shown their interest given that project bonds can perfectly match long-term liabilities with long-term assets and increase their yields. They found the PBI as a good opportunity to diversify their portfolio with long-term assets with interesting characteristics such as long-term and predictable cash flows, low default rates, and low correlation of returns with other asset classes.

\section{Analysis and results}

To determine the specific constraints and attractiveness of the PBI we used the SWOT methodology based on the results of the public consultation about the PBI, and the performance pilot case studies. As mentioned before, in this paper we will focus on the first two topics of the consultation questionnaire (1) feasibility and management of project bonds and (2) cost and efficiency of project bonds.

The SWOT analysis can provide a comprehensive decision support to the PBI. Table 5 summarizes this analysis. The strengths and weaknesses were identified by categorizing the internal factors that enhance or limit the project bonds promoted by the PBI as a financial instrument for large-scale infrastructure. Correspondingly, the opportunities and threats were determined by analyzing and categorizing the external factors that provide positive or negative potential for the PBI. These latter factors cannot be directly modified by the promoters of the initiative, but it is important to keep them under control in order to take advantage of the positive aspects and prevent negative consequences.

Each factor (strength, weakness, opportunity, and threat) came from a careful review of the literature along with the feedback obtained from the pilot case studies and the public consultation. Some references supporting our analysis are shown in the reference column included in Table 5. This analysis will serve as a reference of what is considered acceptable for the appropriate implementation of project bonds. Each factor is described as follows.

\section{Strengths (S)}

S1: Long-term nature of project bonds allows the institutional investors to match their longdated liabilities.

The long-term nature of project bonds will allow the institutional investors to match their long-dated liabilities with long-maturity assets (Christophersen et al. 2014). Consequently, institutional investors will constitute a reliable source of long-term capital for infrastructure projects as long as risks are limited through the PBI.

S2: Despite the fact that project bonds usually have low investment grade ratings, the PBI is a sure means to achieve adequate ratings.

The PBI is nowadays the only way to achieve good ratings for project bonds due to the fact that most of the monoline insurance companies stop wrapping project finance bonds after the financial crisis. As a consequence of that, apart from the EIB, external guarantors hardly ever provide insurance for project finance bonds (Dhondt et al. 2014). 
Table 5. SWOT ansalysis

\begin{tabular}{|c|c|c|}
\hline \multirow{10}{*}{ 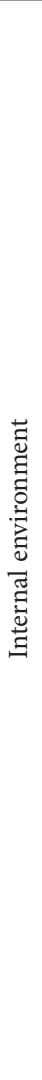 } & Strengths & References \\
\hline & $\begin{array}{l}\text { S1. Long-term nature of project bonds allows the } \\
\text { institutional investors to match their long-dated } \\
\text { liabilities. }\end{array}$ & - Christophersen et al. (2014). \\
\hline & $\begin{array}{l}\text { S2. Despite the fact that project bonds usually have } \\
\text { low investment grade ratings, the PBI is a sure } \\
\text { means to achieve adequate ratings. }\end{array}$ & $\begin{array}{l}\text { - Dhondt et al. (2014). } \\
\text { - Etsy et al. (2014). } \\
\text { - Castor Gas Storage Spain project; OFTO Greater } \\
\text { Gabbard UK project; A11 Belgian motorway } \\
\text { project; A7 Autobahn PPP Germany project; } \\
\text { Axione Telecom Infrastructure France project. }\end{array}$ \\
\hline & $\begin{array}{l}\text { S3. The EC has a great interest and willingness } \\
\text { to enhance the development of the PBI in } \\
\text { order to foster debt capital market financing for } \\
\text { infrastructure projects in Europe. }\end{array}$ & $\begin{array}{l}\text { - European Commission (2011a). } \\
\text { - European Commission (2014a). } \\
\text { - Zaharioaie (2012). }\end{array}$ \\
\hline & $\begin{array}{l}\text { S4. Infrastructure needs in Europe are huge because } \\
\text { the EC is encouraging large-scale investment in the } \\
\text { Trans-European Networks. }\end{array}$ & $\begin{array}{l}\text { - EIB (2015). } \\
\text { - Dhondt et al. (2014). }\end{array}$ \\
\hline & Weaknesses & \\
\hline & $\begin{array}{l}\text { W1. Long-term institutional investors in } \\
\text { Europe lack the knowledge and experience with } \\
\text { infrastructure investment. }\end{array}$ & $\begin{array}{l}\text { - OECD (2014). } \\
\text { - European Commission (2011c). }\end{array}$ \\
\hline & $\begin{array}{l}\text { W2. Moral hazard problems due to the fact that } \\
\text { in order to attract private investors public entities } \\
\text { may end up bearing most of the risk of the } \\
\text { infrastructure projects. }\end{array}$ & $\begin{array}{l}\text { - Castor Gas Storage Spain project. } \\
\text { - Rossi and Stepic (2015). }\end{array}$ \\
\hline & $\begin{array}{l}\text { W3. Much of the infrastructure needs are from the } \\
\text { "greenfield" type, which involves construction risk. }\end{array}$ & - European Commission (2013a). \\
\hline & $\begin{array}{l}\text { W4. The percentage of financing that can be } \\
\text { guaranteed is fixed at } 20 \% \text {. }\end{array}$ & - European Commission (2013a). \\
\hline
\end{tabular}

\section{Opportunities}

O1. Regulatory requirements that constraint

- Della Croce and Gatti (2014).

substantially the borrowing from banks for project - European Commission (2013a).

finance purposes offer a good opportunity to the capital markets.

O2. The PBI constitutes a good opportunity for - European Commission (2013a) institutional investors to acquire inflation-linked securities.

\begin{tabular}{|c|c|}
\hline $\begin{array}{l}\text { O3. The PBI may be a good opportunity to the } \\
\text { institutional investors to diversify their portfolio. }\end{array}$ & $\begin{array}{l}\text { - Scannella (2012). } \\
\text { - Bassanini and Reviglio (2011). } \\
\text { - European Commission (2011a, 2013a). }\end{array}$ \\
\hline $\begin{array}{l}\text { O4. The infrastructure sector has a need for long- } \\
\text { term financing. }\end{array}$ & - European Commission (2011a). \\
\hline \multicolumn{2}{|l|}{ Threats } \\
\hline $\begin{array}{l}\text { T1. Negative perception of the infrastructure value } \\
\text { after the financial crisis. }\end{array}$ & - Della Croce (2011). \\
\hline $\begin{array}{l}\text { T2. Provisions by Solvency II Directive may } \\
\text { negatively affect the interest of investors in project } \\
\text { bonds. }\end{array}$ & - European Commission (2013a, 2014b). \\
\hline $\begin{array}{l}\text { T3. Changes in government rules and regulations } \\
\text { can negatively affect project bonds. }\end{array}$ & - OECD (2013). \\
\hline
\end{tabular}


Through the PBI, the EIB may provide either a layer of subordinated debt or a standby liquidity facility to the project in order to reduce the exposure to the project risk by senior lenders. In order to be attractive to institutional investors, the issued bonds should be rated $\mathrm{A}$ - or $\mathrm{BBB}$ exceptionally. In order to facilitate this, they recommend that rating agencies as well as the EIB/EU get involved as early as possible in the process of issuing bonds (Esty et al. 2014).

In practice, all of the pilot case studies considered in this study were able to offer attractive credit rating to institutional investors; Castor Gas Storage Spain (BBB), Greater Gabbard offshore UK (A3), A11 Belgian motorway (A3), Axione Telecom Infrastructure France (BAA2) and A7 Autobahn Germany (A3).

S3: The EC has a great interest and willingness to enhance the development of the PBI in order to foster debt capital market financing for infrastructure projects in Europe.

The EC is providing plenty of institutional support to enhance the development of well-functioning project finance in order to boost the completion of the Trans-European Networks (European Commission 2011a, 2014a; Zaharioaie 2012).

S4: Infrastructure needs in Europe are huge because the EC is encouraging large-scale investment in the Trans-European Networks.

The European fund for strategic investments (EFSI) or Juncker Plan is actively encouraging investment in Europe's infrastructure to reactivate Erope's economy. The EFSI is a strategic partnership between the European Commission and the EIB aimed at reviving investments in strategic infrastructure including digital, transport and energy projects; and other socially beneficial assets. The idea is to try to overcome the current investment gap in the EU by attracting additional private sector resources to finance long-term infrastructure projects (EIB 2015).

Besides the EU has agreed on a large package of public support for trans-European network projects (Dhondt et al. 2014). The aim is to allocate $€ 33.3$ billion of the EU budget in 2014-2020 to the Connecting Europe Facility (CEF) in order to support the 2020 Agenda of the EC.

\section{Weaknesses (W)}

W1: Long-term institutional investors in Europe lack the knowledge and experience with infrastructure investment.

The debt capital market is largely unexploited for infrastructure investments in Europe. These deals entail complex legal and financial arrangements requiring a lot of expertise. However long-term institutional investors in Europe lack the knowledge and experience with infrastructure investments (OECD 2014). For this reason the PBI essentially act as a catalyst to re-open the debt capital markets as a significant financing source for infrastructure (European Commission 2011c).

W2: Moral hazard problems due to the fact that in order to attract private investors public entities may end up bearing most of the risk of the infrastructure projects. 
After analyzing the case studies, we found that the lack of a suitable due diligence and proper risk allocation may lead to unsuccessful projects that end up being costly for society. The Castor project, for instance, showed that lack of transparency about risk allocation remains a huge issue for many large-scale infrastructure projects. Unfortunately, in many PPP contracts more detailed information about contractual agreement, clauses and absorbed risk is needed.

As mentioned in the last section, the Castor project was the less successful project of the PBI pilot phase due to the poor risk assessment, which helped emerge some structural weaknesses of the project bond mechanism. The first gas injections caused a series of earthquakes so the project had to be halted. The Spanish government ultimately took the losses due to a contractual clause. The government of Spain ended up bearing most of the risk and, ultimately losses were absorbed by taxpayers while profits were privatized (Rossi, Stepic 2015).

W3: Much of the infrastructure needs are from the "greenfield" type of project, which involves construction risk.

Some of the governments that took part in the consultation were a bit sceptical about some issues related to the feasibility and management of project bonds such as the allocation of construction risk. Pension funds do not have the appetite for pre-construction and construction risks of a project because they do not have the expertise required to assess and appraise the value of these risks. Pension funds believe that pre-construction risks could be avoided, for example by involving commercial banks which have the expertise to appraise risks and manage loans at this stage of infrastructure projects.

According to the responses of the stakeholders to the public consultation, institutional investors are not able to absorb the construction risk (European Commission 2013a). They also pointed out moral hazard problems - i.e. the ceiling of $20 \%$ of the total project bond emission as the maximum involvement of the EIB/EC will not ensure the proper transfer of the construction risk to the private partner.

W4: The percentage of financing that can be guaranteed is fixed at $20 \%$.

The EIB does not consider a flexible level for the guarantee offered to the senior debt of the project. The maximum coverage of the Project Bond Credit Enhancement instrument is currently $20 \%$ of the bond issuance. According to the public consultation, a credit enhancement of $20 \%$ of outstanding senior bonds would be sufficient for $10 \%$ of respondents, whereas $5 \%$ of them believe that it would not be enough (see Table 2). The stakeholders stressed that the percentage of financing that can be guaranteed should be flexible depending on the characteristics of each project.

\section{Opportunities $(\mathrm{O})$}

O1: Regulatory requirements that constraint substantially the borrowing from banks for project finance purposes offer a good opportunity to the capital markets.

The new regulation for banks in Europe, called Basel III, has established more conservative rules in order to guarantee the resilience of banks to unexpected events. This fact, 
along with the fact that the banking sector has been under severe financial and regulatory pressure ever since the financial crisis, has reduced their capacity to provide financing for large-scale projects.

The majority of respondents of the consultation agreed on the fact that nowadays there are a number of constrains limiting long-term financing for typical infrastructure projects in the bank lending market (European Commission 2013b). Liquidity requirements under the Basel III have forced financial markets to develop new financial instruments able to attract capital (Della Croce, Gatti 2014).

Because of this constraint, the European Commission has launched the PBI to increase investment in infrastructure projects and reduce bottlenecks. This initiative recognizes that capital markets are an alternative source for funding large-scale infrastructure projects.

O2: The PBI constitutes a good opportunity for institutional investors to acquire inflationlinked securities.

One of the risks inherent to institutional investors is the long-term inflation mismatch that may happen between their assets and liabilities. Project bonds offer a good opportunity for institutional investors to solve this problem through inflation-linked securities which are well suited to infrastructure projects where there revenues are tied to inflation.

In the public consultation, pension funds mentioned this point as a precondition for the attractiveness of the PBI. Being long-term investors by nature, pension institutions can achieve a wider asset diversification by investing in project bonds. However, for pension funds project bonds with low risk rating would be welcomed as long as they were inflation-linked since an index linked-bond inflation risk premium to be paid will be reduced (European Commission 2013a).

O3: The PBI may be a good opportunity for institutional investors to diversify their portfolio.

Institutional investors have a great potential to invest in large-scale infrastructure projects through the capital markets. Besides they are seeking for new sources of long-term returns. Therefore the PBI may be a good opportunity, in particular for insurance companies and pension funds, to diversify their portfolio (Scannella 2012; Bassanini, Reviglio 2011; European Commission 2011a, 2013a).

O4: The infrastructure sector has a need for long-term financing.

There is a substantial gap between current investment levels and those required to reach the 2020 Agenda of the European Commission. Therefore, the capital markets emerge as an alternative source for funding large-scale infrastructure projects. Long-term institutional investors are potential investors for the financial instruments envisioned for project financing (European Commission 2011a).

\section{Threats (T)}

T1: Negative perception of the infrastructure value after the financial crisis.

The poor behavior experienced by infrastructure assets - with important revenue shortfalls and cost overruns during the recession - is influencing the perception that finan- 
cial markets have of the infrastructure business. The investor confidence is crucial for the capital markets as an alternative source of financing long-term infrastructure. In order to mitigate this threat it is crucial to ensure more visibility and promote a more active participation of all the stakeholders in the infrastructure market from the early development of the projects (Della Croce 2011).

T2: Provisions by Solvency II Directive may negatively affect the interest of investors in project bonds.

Many of the responders to the public consultation, especially banks and institutional investors, perceived issues around Solvency II. This regulation would involve a capital charge penalizing long term maturities especially for low investment grade ratings. In order to attract investors, some of the respondents suggested creating a specific asset class for infrastructure/project bonds with lower capital charge compared to the corporate bonds. This may be justified by several analyses showing that project finance has historically shown better recovery performance than corporate bonds (European Commission 2013a, 2014b).

T3: Changes in government rules and regulations can negatively affect project bonds.

Infrastructure is considered to be vulnerable to political issues. Unexpected regulations imposed by the governments that own the infrastructure may negatively affect the financial feasibility of long-term infrastructure projects. Legal and political uncertainty may impact the success of infrastructure projects (OECD 2013) and consequently the feasibility of project bonds.

\section{Conclusions: key challenges to build a market for project bonds}

From the previous analysis we can conclude that institutional investors have a great potential to invest in large-scale infrastructure projects through the capital markets. However the role that these institutions - mostly pension funds and insurance companies - have been playing in continental Europe in the last few decades has been negligible compared to other parts of the world such as the United States, Canada, Australia, and some countries in Latin America.

The new regulatory requirements imposed by Basel III in Europe are going to constraint substantially the borrowing from banks for project finance purposes. However drawing the interest of institutional investors to long-term infrastructure financing is not an easy task. On the one hand, institutional investors require investing in low-risk securities that are hardly compatible with the high leverage demanded by most project finance deals. On the other hand, the monoline insurance market, which used to guarantee a good rating of project finance bonds, has dwindled after the economic recession. This means a great opportunity to develop a project bond market in Europe boosted by the European Union.

All these aspects explain the decision of the European Union to implement certain guarantees for credit enhancement in order to increase the appetite of institutional investors to acquire long-term project bonds. The idea may strengthen a market that has been traditionally very week in continental Europe. The results of the consultation confirm this 
fact. Sixty per cent of the respondents said that the chosen mechanism is likely to attract private sector institutional investor to the sectors of transport, energy and ICT. Fifty per cent of the stakeholders expect lower financial costs and/or longer maturities with this approach. And for forty one per cent of the respondents the guarantee would facilitate, accelerate or both the conclusion of financing packages.

However, according to the SWOT analysis previously conducted some challenges are still to be tackled for the right implementation of this initiative:

1. The first important aspect to be considered has to do with the Strength 2 (S2) described in the previous section. Despite the PBI is the only way to achieve required ratings of project bond up to date, it is important to keep in mind that this mechanism should not replace the role of private firms that in the future may fill the gap that now is intended to be filled by the European Commission and the EIB. The initiative should help project bonds to start running in Europe, but once the market is able to work, the role of this initiative should be reconsidered. Companies such as monoline insurance may emerge again in the future offering market guarantees that play the same role that the EU wants to play nowadays.

2. The second challenge is related to the Weakness 2 (W2): to make sure that project bonds make sense from the social point of view. This approach should be utilized as long as it is cheaper for society. It would be a mistake to make projects cheaper for long-term investors at the expense of the taxpayers. The public guarantees included in the PBI should not end up being a hidden subsidy from taxpayers to the projects for the sake of guaranteeing the repayment of the debt. The case of the Castor pilot project in Spain is a clear example of this problem. The project was ultimately built but will likely never be used. In the end the government of Spain paid for the force majeure guarantee, while bondholders will be ultimately repaid. This fact demonstrates that a clear risk allocation is crucial, as we mentioned in W2. To improve this fact, the European Commission may consider enhancing the technical assistance for EU Members in preparing high-quality projects.

3. The third important challenge is the need to adjust this initiative, particularly at the beginning, to the requirements of institutional investors. In this respect some specific points are worth to be noted:

- The first one is the need to structure bonds with a minimum rating of A- even though lower ratings may be acceptable for small projects. As indicated in the Weakness 4 (W4) according to the opinion of the stakeholders a credit enhancement of $20 \%$ of outstanding senior bonds would be insufficient to achieve this rating in some cases. A little bit more flexibility to set this limit depending on the characteristics of each project seems to be a reasonable measure to adopt. It is important also that rating agencies get involved in the process of the issuing as soon as possible.

- In connection with Weakness 3, a second specific point is how to deal with the construction risk. Institutional investors are very reluctant to take on the construction risk, and consider that the credit enhancement approach offered by the Project Bond Initiative is not enough to cover this risk. As a consequence of this problem, institutional investor will hardly ever finance projects before its operation stage. In this respect the EU has to think whether this risk should be covered somehow to increase 
the appetite for pre-operational bonds, or project bonds should be limited to refinance short-term bank loans assuming the construction risk.

- As indicated in the second opportunity identified (O2), the third point is the great interest showed by pension funds for inflation-linked securities. This may be an option easy to implement in projects whose revenues are also inflation-linked. However, governments are getting more and more reluctant to link prices to inflation in longterm contracts in order to control the evolution of inflation over time.

- Finally, according to the second threat (T2), the fourth point is how to deal with the possible negative impact that Solvency II - the EU regulation of institutional investors - may have on the ability of these institutions to hold long-term bonds. The discussion on Solvency II should carefully take into consideration the best way to account for the risk of long-term infrastructure project bonds.

In the light of the conclusions of this study, we make some recommendations for the implementation of the PBI from a policy perspective:

1. The EC may consider enhancing its technical assistance to improve the preparation of high-quality projects by identifying risk factors from project inception to delivery. As mentioned before, sometimes there is no a connection between contractual obligations and transparency about a contractor's ability to deliver so the society ends up bearing the costs of failures or the consequences of overruns. The PBI will be successful insofar as it means a lower cost for users and taxpayers.

2. According to the present rules the guarantee cannot be higher than $20 \%$ of the bond issuance. This research shows that this limit should be flexible depending on the specific characteristics and needs of every project. This measure will be effective to attract the interest of institutional investors.

3. The PBI is a good opportunity to draw institutional investors to promote not only economic infrastructure, but also social infrastructure (hospitals, education, prisons, housing, recreation and leisure, stadiums, etc.).

4. The EIB should monitor regularly the implementation of projects in cooperation with Member States to ensure the zero tolerance to fraud policy and corruption.

\section{Funding}

The authors wish to thank the Spanish Ministry of Economy and Competitiveness, which has funded the SUPPORT Project - EU Support Mechanisms to Promote Public-Private Partnerships for financing Transeuropean Transport Infrastructure - [TRA2012-36590].

\section{References}

Abadie, R.; MacGray, D. 2013. Capital markets: the rise of non-bank infrastructure project finance. PricewaterhouseCoopers.

Bassanini, F; Reviglio, E. 2011. Financial stability, fiscal consolidation and long-term investment after the crisis, OECD Journal: Financial Market Trends 1: 1-45.

https://doi.org/10.1787/fmt-2011-5kg55qw1vbj1 
Baycheva-Merger, T.; Wolfslehner, B. 2016. Evaluating the implementation of the Pan-European Criteria and indicators for sustainable forest management - A SWOT analysis, Ecological Indicators 60: 1192-1199. https://doi.org/10.1016/j.ecolind.2015.09.009

Beckers, F.; Chiara, N.; Flesch, A.; Maly, J.; Silva, E.; Stegemann, U. 2013. A risk management approach to a successful infrastructure project. Initiation, financing and execution. McKinsey Working paper on risk, 52 .

Bhattacharyay, B. N. 2010. Financing Asia's infrastructure: modes of development and integration of Asian financial markets. Working Paper, no. 229. Asian Development Bank Institute.

Blanc-Brude, F. 2014. Benchmarking long-term investment in infrastructure. Objectives, roadmap and recent progress [online]. IDEHEC - Risk Institure [cited September 2014]. Available from Internet:

http://cib.natixis.com/flushdoc.aspx?filename=Benchmark_Investment_Infrastructure_EN.pdf

Boston Consulting Group. 2013. Global Asset Management. Capitalizing on the recovery.

Brown, K. 2007. Are public-private transactions the future of infrastructure finance?, Public Works Management and Policy 12: 320-324. https://doi.org/10.1177/1087724X07303680

Comino, E.; Ferretti, V. 2016. Indicators-based spatial SWOT analysis: supporting the strategic planning and management of complex territorial systems, Ecological Indicators 60: 1104-1117. https://doi.org/10.1016/j.ecolind.2015.09.003

Christophersen, H.; Bodewig, K.; Secchi, C. 2014. New financial schemes for European transport infrastructure projects. Interim Report.

Daito, N.; Chen, Z.; Gifford, J. L.; Porter, T.; Gudgel, J. E. 2013. Implementing public private partnerships during challenging economic times: case study of the 495 Express lanes on the Virginia portion of the Washington Capital Beltway Project (USA), Case Studies on Transport Policy 1(1-2): 35-45. https://doi.org/10.1016/j.cstp.2013.07.001

Della Croce, R. 2011. Pension funds investment in infrastructure: policy actions. OECD Working Papers on Finance, Insurance and Private Pensions, No. 13, OECD Publishing. https://doi.org/10.1787/5kg272f9bnmx-en

Della Croce, R.; Yermo, J. 2013. Institutional investors and infrastructure financing. OECD Working Papers on Finance, Insurance and Private Pensions, No. 36, OECD Publishing. https://doi.org/10.1787/5k3wh99xgc33-en

Della Croce, R.; Gatti, S. 2014. Financing infrastructure - international trends, OECD Journal: Financial Markets Trends 5(1): 123-138. https://doi.org/10.1787/fmt-2014-5jxvpb4jfrf1

Dhondt, T.; Krawchenko, A.; Traxler, F. 2014. Ad-hoc audit of the pilot phase of the Europe 2020 Project Bond Initiative. Reliance. Ernst \& Young Global Limited.

Esty, B. C.; Chavich, C.; Sesia, A. 2014. An overview of project finance and infrastructure finance - 2014 update. Harvard Business School Background Note 210-061.

EIB. 2010. Capital markets in PPP financing: where we were and where are we going? European Investment Bank.

EIB. 2012. Financing PPPs with project bonds - Issues for public procuring authorities. European Investment Bank.

EIB. 2015. Investment plan for Europe. European Investment Bank.

European Commission. 2011a. A pilot for the Europe 2020 project bond initiative.

European Commission. 2011b. Consultation on the Europe 2020 project bond initiative.

European Commission. 2011c. A pilot for Europe 2020 project bond initiative - legislative proposal adopted by the Commission. MEMO 11/707.

European Commission. 2013a. Consultation on the Europe 2020 Project Bond Initiative: written responses [online], [cited September 2014]. Available from Internet: http://ec.europa.eu/economy_finance/ articles/consultation/written_responses_en.htm 
European Commission. 2013b. Report of the high level expert group on SME and infrastructure financing [online], [cited July 2014]. Available from Internet: http://europa.eu/efc/working_groups/hleg_report_2013.pdf

European Commission. 2014a. The pilot phase of the Europe 2020 project bond initiative - projects [online], [cited September 2014 ]. Available from Internet: http://ec.europa.eu/economy_finance/ financial_operations/investment/europe_2020/index_en.htm

European Commission. 2014b. Supplementing directive 2009/138/EU of the European Parliament and of the Council on the taking-up and pursuit of the business of Insurance and Reinsurance (Solvency II).

European Commission. 2014c. Commission delegated regulation of 10.10.2014 to supplement Regulation (EU) 575/2013 with regard to liquidity coverage requirement for Credit Institutions.

Federal Highway Administration (FHWA). 2009. Transportation Finance Innovations: the Transportation Infrastructure Finance and Innovation Act (TIFIA). Federal Highway Administration, Office of Innovative Program Delivery, Washington, D.C.

Gatti, S. 2013. Project finance in theory and practice. $2^{\text {nd }} \mathrm{ed}$. London: Elsevier inc.

Hellowell, M. 2013. PFI redux? Assessing a new model for financing hospitals, Health Policy 113: 77-85. https://doi.org/10.1016/j.healthpol.2013.09.008

Herring, R. J.; Chatusripitak, N. 2000. The case of the missing market: the bond market and why it matters for financial development. Asian Development Bank Institute/Wharton Seminar on financial structure for sustainable development in post-crisis Asia, Tokyo.

Hill, T.; Westbrook, R. 1997. SWOT analysis: it's time for a product recall, Long Range Planning 30: 46-52. https://doi.org/10.1016/S0024-6301(96)00095-7

Jaber, J. O.; Elkarmi, F.; Alasis, E.; Kostas, A. 2015. Employment of renewable energy in Jordan: current status, SWOT and problem analysis, Renewable and Sustainable Energy Reviews 49: 490-499. https://doi.org/10.1016/j.rser.2015.04.050

Jacobsson, R.; Jacobsson, S. 2012. The emerging funding gap for the European Energy Sector - will the financial sector deliver?, Environmental Innovation and Societal Transitions 5: 49-59. https://doi.org/10.1016/j.eist.2012.10.002

Latham and Watkins. 2009. Why project bonds now?, Client Alert 914: 1-6.

Marowa, Y.; Muyengwa, G. 2015. Risk assessment in infrastructural projects, in International Association for Management of technology IAMOT Conference Proceedings, 8-11 June 2011, University of Pretoria, Cape Town, South Africa.

Mbeng Mezui, C. 2012. Accessing local markets for infrastructure: lessons for Africa. Working paper, No 153, African Development Bank Group,.

OECD. 2013. The potential of private institutional investors for financing transport infrastructure. Discussion Paper No.14.

OECD. 2014. Are institutional investors the answer for long-term development financing? Development Co-operation Report 2014. Mobilising Resources for Sustainable Development.

Rossi, E.; Stepic, R. 2015. Infrastructure project finance and project bonds in Europe. Basingstoke: Palgrave Macmillan. https://doi.org/10.1057/9781137524041

Scannella, E. 2012. Project finance in the energy industry: new debt-based financing models, International Business Research 5(2): 83-93. https://doi.org/10.5539/ibr.v5n2p83

Siemiatycki, M. 2013. Pension fund investors in transport infrastructure: opportunities and barrier, in Workshop "The desired and undesired effects of infrastructure and transport policy reforms", 29 November 2013, Universidad de Barcelona, Spain.

Zaharioaie, M. 2012. Appropriate financial instruments for public-private partnership in European Union, Procedia Economics and Finance 3: 800-805.

https://doi.org/10.1016/S2212-5671(12)00233-X 
José Manuel VASSALLO is Professor in the Transportation Department at the Civil Engineering School (UPM), and a member of the academic staff of the Transportation Research Centre (TRANSYT) of the UPM where he leads the transport management and financing research area. He was research fellow at the Kennedy School of Government (Harvard University) where he did research with Professor Gómez Ibáñez in the field of transport financing, contracting and regulation. Presently, José Manuel Vassallo teaches "Transport Economics and Planning" and "Infrastructure Management and Financing" in Madrid. His research activity during the last years has been focused on transportation management and financing, infrastructure regulation, socioeconomic evaluation of projects, and public-private partnerships. In his academic career, he has published 6 books and more than 30 papers in prestigious journals (Transportation, Journal of Transport Economics and Policy, Transportation Research Record, Public Money and Management etc.). José Manuel Vassallo has also received several awards for his research and publications. He has also worked for several institutions such as the World Bank, the European Investment Bank, the Government of Chile, the Andean Corporation of Development, and the European Conference of Ministers of Transportation.

Thais RANGEL is a Post-doctoral researcher at the Universidad Politécnica de Madrid. She obtained a BSc. degree in Business Administration from the Mackenzie University of Sao Paulo, where she was awarded a scholarship for 4 years. She was appointed research fellow at the Transport Research Centre (TRANSyT) to work with Professor José Manuel Vassallo in a Research Programme funded by the European Investment Bank. In 2007 she was awarded a scholarship from Spain's Ministry of Foreign Relations (Carolina Foundation Programme). Presently, her research activity is focused on the Financing of Transport Infrastructures. In her academic career, she has participated in the elaboration of 2 books and 6 papers in prestigious journals (Accident Analysis and Prevention, Transport Policy, Transportation Research Part A: Policy and Practice, Public Money \& Management, and so on).

María de los Ángeles BAEZA is a Lecturer in the Department of Financial Economic and Accounting at the Faculty of Economics and Business Studies, University of Granada (UGR). She got her PhD with the highest grade under the direction of Professor Vassallo. Her thesis was about an empirical evaluation of the accuracy of the estimates conducted by concessionaires in toll road concessions in Spain. Presently, María de los Ángeles Baeza teaches "Management of Fixed Income Securities" in Granada. Her research activity during the last years has been focused on the Financing of Transport Infrastructure and public-private partnerships. In her academic career, she has participated in the elaboration of 6 papers in prestigious journals (Public Money \& Management, Proceedings of the Institution of Civil Engineers-Transport, Canadian Journal of Civil Engineering, Journal of Management in Engineering and Transportation Research Record).

Paola Carolina BUENO is a PhD Candidate at the Faculty of Civil Engineering, Universidad Politécnica de Madrid where she obtained a M.Sc. in the Transportation area. After her BSc. degree in Civil Engineering from the Universidad de los Andes (Colombia), she began to work as a mobility analyst where she designed and developed the first mobility observatory of Bogotá and the Region and spearheaded the monitoring of strategic transport projects in the City of Bogotá. During last years, she was working on the development of local transport plans and transport policy designs. Recently she was appointed research fellow at the Transport Research Centre (TRANSyT) to investigate in areas of transportation planning, transportation management and financing, transport modelling and socioeconomic evaluation of projects. Presently, her research activity is centred on transport, infrastructure management, sustainability, equity and financing. In her academic career, she has published 1 book and more than 10 papers in prestigious journals (Transport Reviews, Transport, Transportation Research Record) and conference proceedings (Transportation Research Board, Transport Research Arena, etc). She has also worked for several institutions such as the European Investment Bank, the Development Bank of Latin America and the City University of New York. 